\title{
Phytotoxicity, cytotoxicity and antioxidant activity of the invasive shrub Austroeupatorium inulifolium (Kunth) R.M. King \& H. Rob
}

\author{
Indika Chandrasiri ${ }^{1}$, Shashini Diwakara ${ }^{1}$, Chamara Janaka Bandara ${ }^{1}$, Siril Wijesundara ${ }^{2}$, Sumedha \\ Madawala $^{3^{*}}$ and Veranja Karunaratne ${ }^{1,4}$ \\ ${ }^{1}$ Department of Chemistry, University of Peradeniya, Peradeniya, Sri Lanka. \\ ${ }^{2}$ Royal Botanic Gardens, Peradeniya, Sri Lanka. \\ ${ }^{3}$ Department of Botany, University of Peradeniya, Peradeniya, Sri Lanka. \\ ${ }^{4}$ Sri Lanka Institute of Nanotechnology, Homagama, Sri Lanka. \\ Accepted December 31, 2015
}

\begin{abstract}
Methanol and dichloromethane extracts of root, stem, leaves and flowers of invasive plant Austroeupatorium inulifolium were tested for cytotoxic, phytotoxic, antioxidant and antifungal activities. Significantly higher phytotoxicity was detected in methanol extracts of leaves and dichloromethane extracts of roots. This effect was most pronounced against amaranth seeds where the seed germination was reduced to $3.74 \%$ with the addition of methanol extracts of leaves at $3000 \mathrm{mg} / \mathrm{L}$. The dichloromethane extract of roots of $A$. inulifolium showed potent antifungal activity against Cladosporium cladosporioides. Cytotoxic activity was found in dichloromethane extract of roots $\left(\mathrm{LD}_{50}=27.91 \pm 8.55 \mathrm{mg} / \mathrm{L}\right)$, methanol extract of flowers $\left(\mathrm{LD}_{50}=15.22 \pm 7.89\right.$ $\mathrm{mg} / \mathrm{L})$ and leaves $\left(\mathrm{LD}_{50}=22.92 \pm 11.76 \mathrm{mg} / \mathrm{L}\right)$ against Artemiasalina (brine shrimp) larvae. The results also revealed significant antioxidant activity in methanol extract of leaves $\left(\mathrm{IC}_{50}=33.66 \pm 0.03 \mathrm{mg} / \mathrm{L}\right)$ against the reference $\alpha$-tocopherol $\left(\mathrm{IC}_{50}=10.02 \pm 0.01 \mathrm{mg} / \mathrm{L}\right)$.
\end{abstract}

Keywords: invasive plant, cytotoxicity, phytotoxicity, antioxidant and antifungal activities.

\section{INTRODUCTION}

Plants have co-evolved with their respective environments for millions of years. During this process, secondary metabolites played a critical role in plants' adaptations to insect and microbial attacks and climatic conditions. Plant metabolites with various bioactivities including phytotoxic and antioxidant activities allow plants to live in a state of equilibrium with the environment. However, some plant species use these bioactivities to transform themselves into noxious weeds. The indigenous flora of Sri Lanka comprises about 7,500 species. Of the 3,154 flowering plants, about $894(28 \%)$ species are endemic to the island, some carrying varying levels of biological activity (Wijesundara et al., 2012; Bandara et al., 1989a; Bandara et al., 1990a; Hewage et al., 1997; Hewage et al., 1998). Many bioactivities in plants have been used in medicinal applications (Banadara et al., 1989b; Bandaraet al., 1989c; Bandaraet al., 1990b; Williams et al., 2011). Plant ecologists were always puzzled by the fact that exotic plant species with low densities in their native ranges eventually produce large populations in their introduced ranges. The 'novel weapons hypothesis' proposed that these exotic plants possess novel biochemical compounds with powerful bioactivities (Callaway and Ridenour, 2004). Austroeupatorium inulifolium (Kunth)
King and Robinson (Asteraceae) which is an aggressive invasive shrub native to South America has become a noxious invader in the up-country, wet zone of Sri Lanka, invading many natural and man-made ecosystems (Madawala et al., 2014). It is also listed as an 'agricultural and environmental weed in the Global Compendium of weeds (Randall, 2012). Even though it has been well identified as an invasive plant in many countries, it has been categorized as an invasive plant in Sri Lanka fairly recently. $A$. inulifolium has been invading the Cymbopogon-dominated grasslands in the Knuckles Conservation Area (KCA), displacing the grass. Once established, $A$. inulifolium can form mono-specific stands in their introduced range, influencing the growth and survival of the native flora (Haluwana and Madawala, 2013).

There have been many hypotheses to explain the mechanisms of exotic plant invasions into new landscapes and among them the 'novel weapon hypothesis' has attracted contrasting views since it was proposed in 2004 (Blair et al., 2006; Duke et al., 2009). According to this hypothesis, some exotic species credit their success of spread due to the production of bioactive compounds that native species never encountered before (Callaway and Ridenour, 2004; Thorpe et al., 2009; Callaway and Aschehoug, 2000). Previous studies on other

*Corresponding author's email: sumedha.madawala@gmail.com 
invasive species have confirmed the presence of bioactive compounds (Yan et al., 2010; Shao et al., 2010; Ens et al., 2009; Xie et al., 2010). These bioactive compounds can reach the soil environment through leaching, root exudation or litter decomposition. In the present study, we attempted to investigate the potential role of bioactive compounds in $A$. inulifolium by using bioassays with extracts of different parts of the shrub including stems, roots, flowers and leaves and to relate them to its invasive success. Apart from the isolation of nine new norlabdane derivatives with antimicrobial activity in $A$. inulifolium (Saito et al., 2011), no studies have been carried out to assess the bioactive profile of $A$. inulifolium with an aim to explain its invasive nature of the plant. We report herein, the bioactivities of A. inulifolium including cytotoxic, phytotoxic, antioxidant and antifungal properties.

\section{MATERIALS AND METHODS}

Austroeupatorium inulifolium, belongs to the family Asteraceae, is a shrub that can grow up to 1-5 $\mathrm{m}$ in height. It bears a creamy white fragrant inflorescence (Figure 1). Leaves are opposite, spear-shaped and pubescent, abruptly narrowing to a wedge-shaped petiole. It is well known as an aggressive invader in many countries.

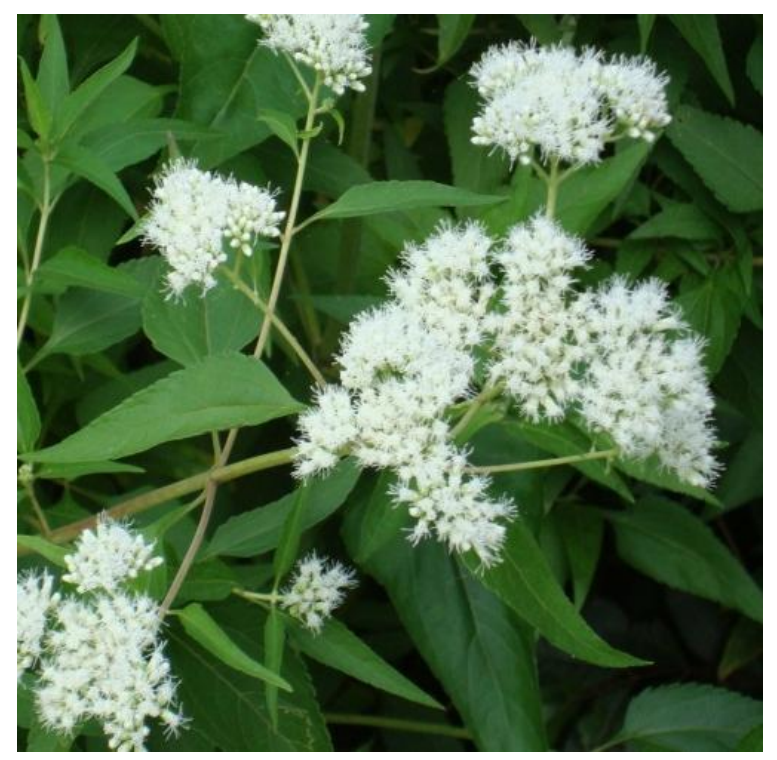

Figure 1. The creamy white inflorescence of $A$. inulifolium. (Photo Credit: InokaPiyasinghe).

\section{Extraction of potential bioactive compounds}

Plant samples were collected from Riverston area in the Knuckles Forest Reserve (KFR) in the central of Sri Lanka. Plant parts (roots, stems, leaves and flowers) were separated and air-dried before grinding into a powder. The resulting powdered plant material $(\approx 600 \mathrm{~g})$ was subjected to sequential extraction with $5 \mathrm{~L}$ of $\mathrm{CH}_{2} \mathrm{Cl}_{2}$ and $\mathrm{CH}_{3} \mathrm{OH}$ separately after maceration for 24 hours (in cleaned and dried glass bottles) with constant shaking. The extract was then filtered and concentrated using a rotary evaporator at $30{ }^{\circ} \mathrm{C}$ to obtain the final yield of extract in paste form. The crude extract was then stored at $4{ }^{\circ} \mathrm{C}$ until further use. The $\mathrm{CH}_{2} \mathrm{Cl}_{2}$ and $\mathrm{CH}_{3} \mathrm{OH}$ crude extracts were subjected to cytotoxic, phytotoxic, antioxidant and antifungal bioassays.

\section{Cytotoxic Activity}

Cytotoxic activity was determined using a brine shrimp lethality assay (McLaughlin, 1982). Brine shrimp eggs were added to fresh artificial sea water and allowed to hatch in a beaker which was aerated and illuminated using a $20 \mathrm{~W}$ bulb. The temperature was maintained at $27^{\circ} \mathrm{C}$. A series of concentrations $(0.75,2,7.5,20,75,200,750,2000$ $\mathrm{mg} / \mathrm{L}$ ) of the dichloromethane and methanol extracts of different plant parts were tested with 1day old brine shrimps (three replicates and 10 shrimps per experiment). After 24 hours, the number of surviving nauplii of brine shrimps was counted and $\mathrm{LD}_{50}$ value (concentration at $50 \%$ survival) was calculated using probit analysis of MINITAB version 16 . The known cyctotoxic lactone, (4 S)-4-methyl-2-(11-dodecynyl)-2 butenolide, from the genus Hortonia was used as the positive control (Ratnayake et al., 2001).

\section{Phytotoxic activity}

The phytotoxic activity was determined using a seed assay with two monocot species, maize (Zea mays) and bluegrass (Poa sp.), and two dicot species, amaranth (Amaranthus sp.) and radish (Raphanus sativus). Ten seeds (surface sterilized with $0.5 \% \mathrm{HgCl}_{2}$ ) from each species were treated with $5 \mathrm{ml}$ of 250,750 and $3000 \mathrm{mg} / \mathrm{L}$ of the $\mathrm{CH}_{2} \mathrm{Cl}_{2}$ and $\mathrm{CH}_{3} \mathrm{OH}$ extracts of different plant parts in petri dishes ( $9 \mathrm{~cm}$ diameter) lined with Whatman No. 3 filter paper. Distilled water mixed with $1 \% \mathrm{DMSO}$ (v/v \%) was used as the negative control and [(4S)4-methyl-2-(11-dodecynyl)-2-butenolide] as the positive control. Petri dishes were sealed with Parafilm to prevent any water losses and the petri plates were stored in the dark at room temperature. Tests were carried out in triplicate for each concentration. Cumulative germination was determined by counting the number of germinated seeds daily over a period of 6 days and the Germination Index was calculated using the formula (Chiapuso et al.,1997),

$\mathrm{GI}=\left(\mathrm{N}_{1}\right) \times 1+\left(\mathrm{N}_{2}-\mathrm{N}_{1}\right) \times 1 / 2+\left(\mathrm{N}_{3}-\mathrm{N}_{2}\right) \times 1 / 3+\ldots$. $+\left(\mathrm{N}_{\mathrm{n}}-\mathrm{N}_{\mathrm{n}-1}\right) \times 1 / \mathrm{n}$, where $\mathrm{N}_{1}, \mathrm{~N}_{2}, \mathrm{~N}_{3} \ldots \mathrm{N}_{\mathrm{n}}$ : proportion of germinated seeds observed afterwards $1,2,3 \ldots \mathrm{n}-1$ and $\mathrm{n}$ is the number of days. On the 7 th day, shoot and root lengths of the seedlings were measured. The inhibitory or stimulatory percentage was calculated using the 
equation (Chung et al., 2001), Inhibition (-) or Stimulation $(+) \%=($ Extract - Control $) /($ Control $)$ $\times 100$.

\section{Antioxidant activity}

Antioxidant activity was determined using 2, 2diphenyl-1-picrylhydrazyl (DPPH) radical scavenging assay (Budzianowski and Budzianowska, 2006). The reduction of DPPH in the extract was measured using a concentration series ranging from $1-500 \mathrm{mg} / \mathrm{L}$ at $517 \mathrm{~nm}$ using a UV-visible spectrophotometer (Shimadzu UV1800) after 30 minutes against the $\mathrm{CH}_{3} \mathrm{OH}$ blank. The initial absorbance of DPPH and each test solution (without DPPH) were measured at $517 \mathrm{~nm}$ separately. $\alpha$ - Tocopherol (Vitamin E), concentration series ranging from $1-500 \mathrm{mg} / \mathrm{L}$ was used as the positive control. Tests were carried out in triplicate for each concentration. Percentage antioxidant activity was calculated using absorbance readings using the equation, $\left[\mathrm{A}_{0}\right.$ $\left.A_{t} / A_{t}\right] \times 100$ where $A_{0}$ is the initial absorbance value and $A_{t}$ is the absorbance of the test sample after 30 min of adding DPPH. The \% antioxidant activity was plotted against the concentration gradient for all three trials separately and trend lines were constructed for the linear range of the plot. The $\mathrm{IC}_{50}$ value was calculated for each trend line from which the average was taken.

\section{Antifungal activity}

Quantitative analysis of antifungal activity using the TLC bioassay method with the fungus, Cladosporium cladosporioides was carried out. A concentration series of the extracts $(250,750$ and $2500 \mathrm{mg} / \mathrm{L}$ ) of different plant parts was prepared and spotted on a TLC plate. A conidial suspension of $C$. cladosporioides was carefully sprayed using an atomizer onto the TLC plates. After 2 days of incubation, the presence of antifungal compounds was detected using inhibition zones. Antifungal active spots appeared white against the background of grey-green mycelia.

\section{RESULTS AND DISCUSSION \\ Yields of potential bioactive extracts}

After extraction and concentration, crude yields of methanol and dichloromethane extracts of different plant parts of $A$. inulifolium were obtained (Table 1). In both extracts, the highest percentage yield was obtained from the leaves.

\section{Cytotoxic effects}

Moderate cytotoxic activity was detected in the $\mathrm{CH}_{2} \mathrm{Cl}_{2}$ extract of roots $(27.91 \pm 8.55 \mathrm{mg} / \mathrm{L})$, and $\mathrm{CH}_{3} \mathrm{OH}$ extracts of leaves $(22.92 \pm 11.76)$ and flowers $(15.22 \pm 7.89)$. The $\mathrm{LD}_{50}$ value of the positive control, (4 S)-4-methyl-2-(11dodecynyl)-2 butenolide, was $0.80 \mathrm{mg} / \mathrm{L}( \pm 0.37)$.

\section{Phytotoxic activity}

Germination index (GI) generally decreased with increasing concentrations of $\mathrm{CH}_{3} \mathrm{OH}$ and $\mathrm{CH}_{2} \mathrm{Cl}_{2}$ extracts of $A$. inulifolium (Table 2). However, $\mathrm{CH}_{3} \mathrm{OH}$-leaf, $\mathrm{CH}_{2} \mathrm{Cl}_{2}$-root and $\mathrm{CH}_{2} \mathrm{Cl}_{2}$-stem extracts showed the most significant reductions in germination index with increasing concentrations (from 250 to $3000 \mathrm{mg} / \mathrm{L}$ ). As an example, $\mathrm{CH}_{3} \mathrm{OH}$-leaf extracts decreased the GI from about $68 \%$ to $4 \%$ in amaranth seeds, while $\mathrm{CH}_{2} \mathrm{Cl}_{2}$-root extracts reduced the GI of same seeds from $61 \%$ to $8 \%$, when increase the concentration from 250 $\mathrm{mg} / \mathrm{L}$ to $3000 \mathrm{mg} / \mathrm{L}$. In contrast, all concentrations of $\mathrm{CH}_{2} \mathrm{Cl}_{2}$-flower extracts showed no influence on the germination of seeds tested in the assay. $\mathrm{CH}_{2} \mathrm{Cl}_{2}$-leaf extracts too showed no impact on the germination of maize seeds.

Both $\mathrm{CH}_{3} \mathrm{OH}$ and $\mathrm{CH}_{2} \mathrm{Cl}_{2}$ extracts of $A$. inulifolium roots and shoots negatively influenced the growth of both monocot and dicot seedlings tested, and this inhibition gradually increased with increasing concentrations (Figure 2). $\mathrm{CH}_{3} \mathrm{OH}$ extracts of $A$. inulifolium leaves negatively affect the growth of seedlings while $\mathrm{CH}_{2} \mathrm{Cl}_{2}$ extracts did not show clear inhibition apart from amaranth seedlings.

Table 1. Mass and the yield (as a percentage) of methanol and dichloromethane crude extracts of different plant parts of $A$. inulifolium collected from Riverston area in the Knuckles Forest Reserve, Sri Lanka.

\begin{tabular}{llllll}
\hline Plant part & Dry mass (g) & $\begin{array}{l}\text { Mass of } \\
\mathrm{CH}_{3} \mathrm{OH} \\
\text { crude } \\
\text { extract } \\
( \pm 0.001 \mathrm{~g})\end{array}$ & $\begin{array}{l}\text { \% yield } \\
\text { of } \mathrm{CH}_{3} \mathrm{OH} \\
\text { crude extract }\end{array}$ & $\begin{array}{l}\text { Mass of } \\
\mathrm{CH}_{2} \mathrm{Cl}_{2} \text { crude } \\
\text { extract } \\
( \pm 0.001 \mathrm{~g})\end{array}$ & $\begin{array}{l}\text { \% yield of } \\
\mathrm{CH}_{2} \mathrm{Cl}_{2} \text { crude } \\
\text { extract }\end{array}$ \\
& & & & \\
\end{tabular}


Table 2. Germination Index (GI, \%) of monocot (maize and bluegrass) and dicot (amaranth and radish) seeds under different concentrations $(250,750$ and $3000 \mathrm{mg} / \mathrm{L})$ of plant extracts of A. inulifolium.

\begin{tabular}{|c|c|c|c|c|c|}
\hline \multirow[b]{2}{*}{ Extract } & \multirow[b]{2}{*}{ Conc. (mg/L) } & \multicolumn{2}{|c|}{ Monocots } & \multicolumn{2}{|l|}{ Dicots } \\
\hline & & Maize & Bluegrass & Amaranth & Radish \\
\hline \multirow[t]{2}{*}{$\mathrm{CH}_{2} \mathrm{Cl}_{2}$-leaf } & 250 & $98.1^{\mathrm{a}}$ & $88.1^{\mathrm{a}}$ & $83.6^{\mathrm{a}}$ & $95.0^{\mathrm{a}}$ \\
\hline & $\begin{array}{l}750 \\
3000\end{array}$ & $\begin{array}{l}90.6^{\mathrm{a}} \\
89.9^{\mathrm{a}}\end{array}$ & $\begin{array}{l}77.2^{\mathrm{ab}} \\
69.4^{\mathrm{b}}\end{array}$ & $\begin{array}{l}71.7^{\mathrm{b}} \\
43.2^{\mathrm{c}}\end{array}$ & $\begin{array}{l}86.2^{\mathrm{b}} \\
71.5^{\mathrm{c}}\end{array}$ \\
\hline \multirow[t]{2}{*}{$\mathrm{CH}_{3} \mathrm{OH}$-leaf } & 250 & $98.9^{a}$ & $89.5^{\mathrm{a}}$ & $67.6^{\mathrm{a}}$ & $79.4^{\mathrm{a}}$ \\
\hline & $\begin{array}{l}750 \\
3000\end{array}$ & $\begin{array}{l}91.3^{\mathrm{a}} \\
74.8^{\mathrm{b}}\end{array}$ & $\begin{array}{l}68.8^{b} \\
60.8^{b}\end{array}$ & $\begin{array}{l}46.8^{b} \\
3.7^{\mathrm{c}}\end{array}$ & $\begin{array}{l}68.3^{\mathrm{b}} \\
44.1^{\mathrm{c}}\end{array}$ \\
\hline \multirow[t]{2}{*}{$\mathrm{CH}_{2} \mathrm{Cl}_{2}$-flower } & 250 & $101.8^{\mathrm{a}}$ & $98.7^{\mathrm{a}}$ & $92.5^{\mathrm{a}}$ & $92.2^{\mathrm{a}}$ \\
\hline & $\begin{array}{l}750 \\
3000\end{array}$ & $\begin{array}{l}97.0^{\mathrm{a}} \\
88.6^{\mathrm{a}}\end{array}$ & $\begin{array}{l}93.3^{\mathrm{a}} \\
91.9^{\mathrm{a}}\end{array}$ & $\begin{array}{l}90.3^{\mathrm{a}} \\
89.5^{\mathrm{a}}\end{array}$ & $\begin{array}{l}88.7^{\mathrm{a}} \\
86.1^{\mathrm{a}}\end{array}$ \\
\hline \multirow[t]{2}{*}{$\mathrm{CH}_{3} \mathrm{OH}$-flower } & 250 & $95.1^{\mathrm{a}}$ & $92.7^{\mathrm{a}}$ & $89.1^{\mathrm{a}}$ & $90.0^{\mathrm{a}}$ \\
\hline & $\begin{array}{l}750 \\
3000\end{array}$ & $\begin{array}{l}87.6^{\mathrm{ab}} \\
80.9^{\mathrm{b}}\end{array}$ & $\begin{array}{l}88.3^{\mathrm{a}} \\
77.4^{\mathrm{b}}\end{array}$ & $\begin{array}{l}72.5^{b} \\
48.3^{c}\end{array}$ & $\begin{array}{l}72.1^{b} \\
66.8^{c}\end{array}$ \\
\hline \multirow[t]{3}{*}{$\mathrm{CH}_{2} \mathrm{Cl}_{2}$-root } & 250 & $99.9^{a}$ & $87.4^{\mathrm{a}}$ & $61.4^{\mathrm{b}}$ & $98.3^{\mathrm{a}}$ \\
\hline & 750 & $69.9^{b}$ & $57.8^{\mathrm{b}}$ & $42.0^{c}$ & $91.7^{\mathrm{a}}$ \\
\hline & 3000 & $61.1^{\mathrm{b}}$ & $35.3^{c}$ & $8.2^{\mathrm{d}}$ & $75.0^{\mathrm{b}}$ \\
\hline \multirow[t]{2}{*}{$\mathrm{CH}_{3} \mathrm{OH}$-root } & 250 & $89.2^{\mathrm{ab}}$ & $61.5^{\mathrm{b}}$ & $68.3^{b}$ & $100.0^{\mathrm{a}}$ \\
\hline & $\begin{array}{l}750 \\
3000\end{array}$ & $\begin{array}{l}63.8^{\mathrm{c}} \\
74.1^{\mathrm{bc}}\end{array}$ & $\begin{array}{l}63.3^{b} \\
30.5^{c}\end{array}$ & $\begin{array}{l}58.0^{\mathrm{bc}} \\
51.1^{\mathrm{c}}\end{array}$ & $\begin{array}{l}92.8^{\mathrm{b}} \\
93.9^{\mathrm{b}}\end{array}$ \\
\hline \multirow[t]{2}{*}{$\mathrm{CH}_{2} \mathrm{Cl}_{2}$-stem } & 250 & $80.3^{\mathrm{ab}}$ & $72.8^{b}$ & $98.3^{\mathrm{a}}$ & $61.3^{\mathrm{b}}$ \\
\hline & $\begin{array}{l}750 \\
3000\end{array}$ & $\begin{array}{l}65.2^{b} \\
40.9^{c}\end{array}$ & $\begin{array}{l}52.4^{\mathrm{c}} \\
8.8^{\mathrm{d}}\end{array}$ & $\begin{array}{l}52.9^{\mathrm{c}} \\
7.8^{\mathrm{d}}\end{array}$ & $\begin{array}{l}89.2^{\mathrm{ab}} \\
76.4^{\mathrm{b}}\end{array}$ \\
\hline \multirow[t]{3}{*}{$\mathrm{CH}_{3} \mathrm{OH}$-stem } & 250 & $90.2^{\mathrm{ab}}$ & $75.3^{\mathrm{b}}$ & $58.2^{\mathrm{b}}$ & $98.3^{\mathrm{ab}}$ \\
\hline & 750 & $85.1^{\mathrm{b}}$ & $59.9^{\mathrm{b}}$ & $56.3^{\mathrm{b}}$ & $92.2^{\mathrm{ab}}$ \\
\hline & 3000 & $49.7^{\mathrm{c}}$ & $25.9^{\mathrm{c}}$ & $35.0^{\mathrm{c}}$ & $92.8^{\mathrm{b}}$ \\
\hline
\end{tabular}

Means with the same letters in a column (between different concentrations) indicate no significant differences at $\mathrm{P}<0.05$.

Interestingly, $\mathrm{CH}_{3} \mathrm{OH}$-leaf and $\mathrm{CH}_{3} \mathrm{OH}$-flower extracts showed higher inhibition on the growth of dicot seedlings compared to that of monocots. In contrast to the effects of other extracts, $\mathrm{CH}_{2} \mathrm{Cl}_{2}$ flower extracts stimulated the growth of dicot and monocot seedlings, showing highest stimulatory effect at $250 \mathrm{mg} / \mathrm{L}$ concentration, though the differences are not significant. Furthermore, the monocot seedlings were more stimulated than that of dicot seedlings (Figure 2).

\section{Antioxidant activity of $A$. inulifolium}

When comparing the antioxidant activity of
$\mathrm{CH}_{3} \mathrm{OH}$ and $\mathrm{CH}_{2} \mathrm{Cl}_{2}$ extracts of $A$. inulifolium with $\alpha$-tocopherol $\left(\mathrm{IC}_{50}=10.02 \pm 0.01 \mathrm{mg} / \mathrm{L}\right)$, the $\mathrm{CH}_{3} \mathrm{OH}$ extract of leaves $\left(\mathrm{IC}_{50}=33.66 \pm 0.03 \mathrm{mg} / \mathrm{L}\right)$ showed a significant antioxidant activity among the extracts at $\mathrm{P}<0.05$.

\section{Antifungal activity of $A$. inulifolium}

Interestingly, the antifungal activity was only observed in $\mathrm{CH}_{2} \mathrm{Cl}_{2}$-root extracts. According to the results obtained, the average diameters of inhibition zones shown in the presence of the $\mathrm{CH}_{2} \mathrm{Cl}_{2}$ extract of Austroeupatorium roots were 16.0 and $24.6 \mathrm{~mm}$ at concentrations 750 and 2500 
$\mathrm{mg} / \mathrm{L}$, respectively (Table 3).
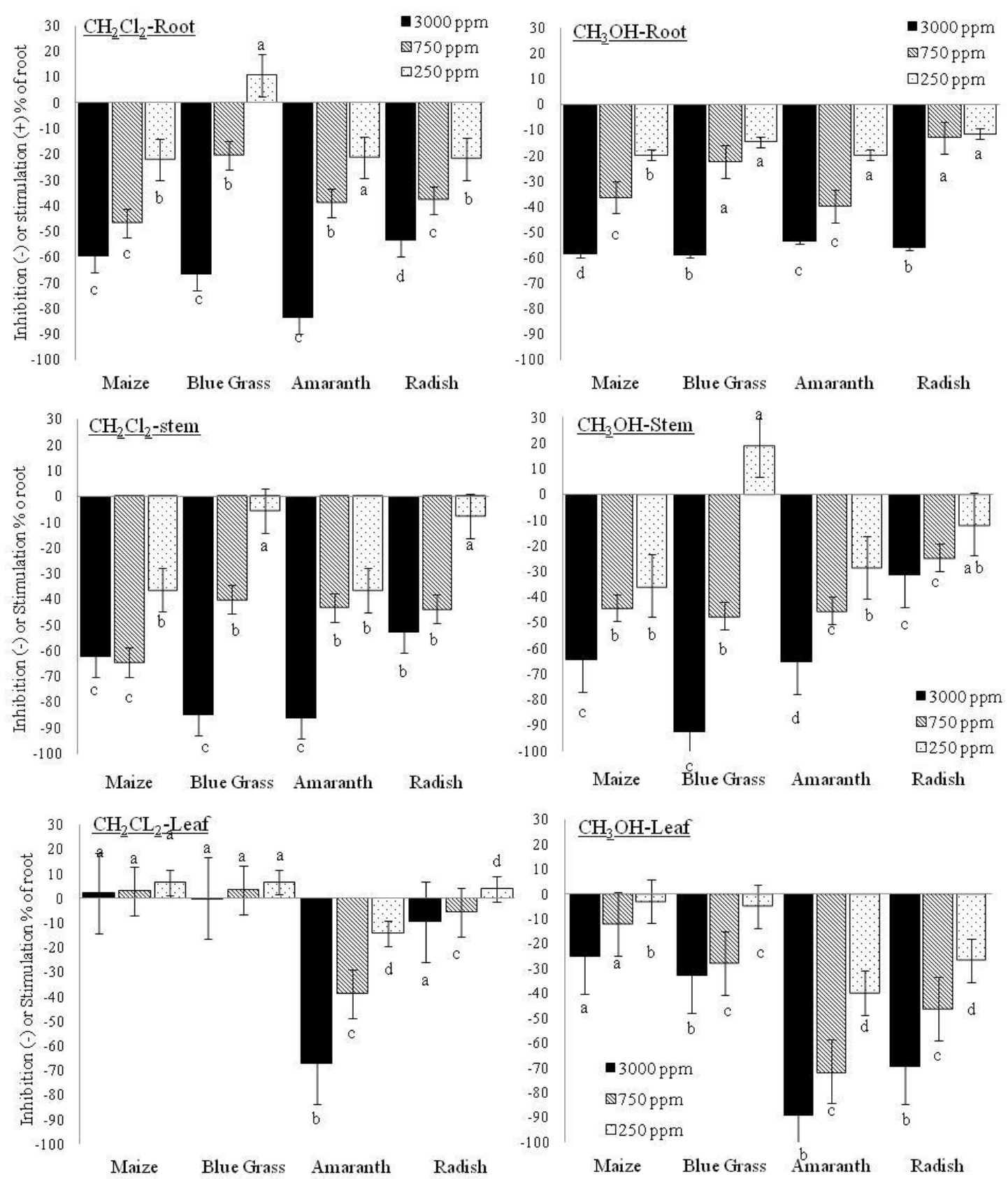

$\underline{\mathrm{CH}}_{2} \underline{\mathrm{OH}-\mathrm{Leaf}}$
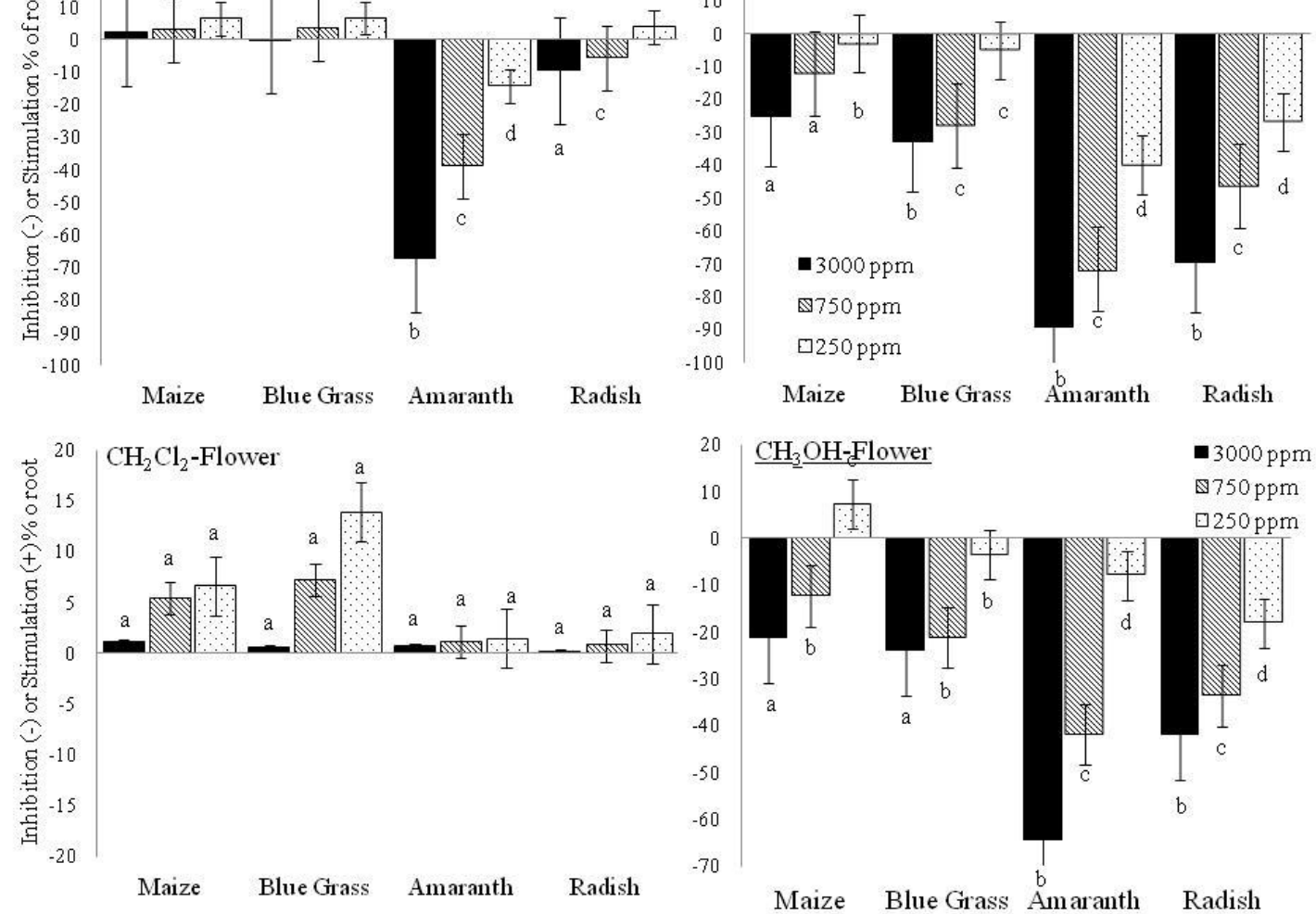

Figure 2. Inhibitory or Stimulatory effects (\%) of different concentrations (250, 750 and $3000 \mathrm{mg} / \mathrm{L})$ of $A$. inulifolium extracts on the growth of monocot (maize and bluegrass) and dicot (amaranth and radish) seedlings. 
Different letters indicate significant differences among concentrations at $\mathrm{P}<0.05$.
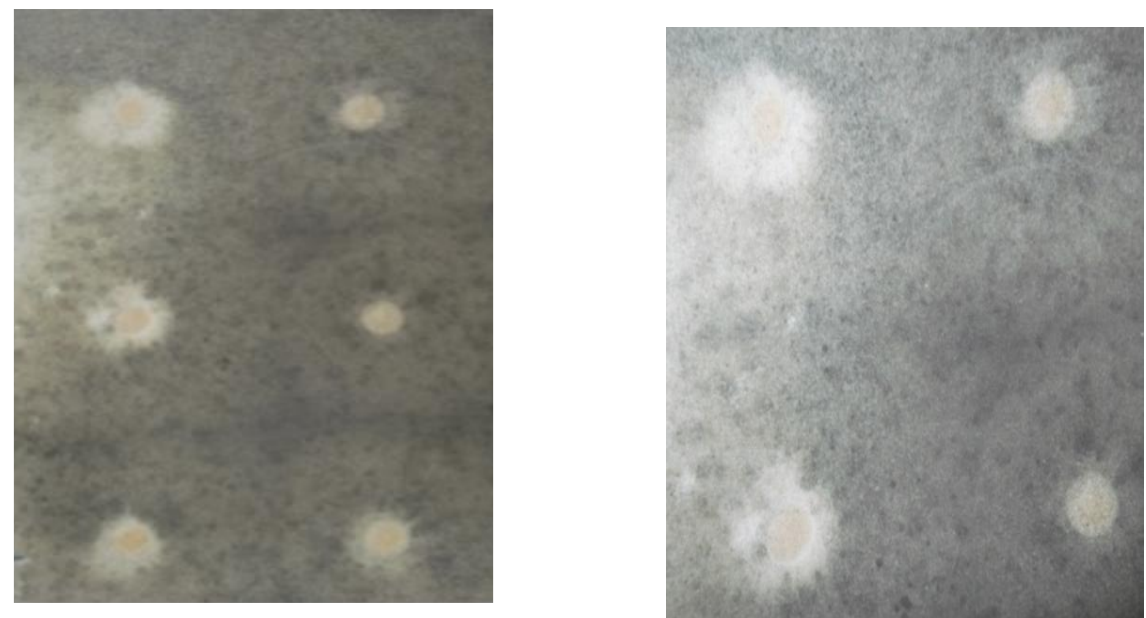

Figure 3. Inhibition zones given by $\mathrm{CH}_{2} \mathrm{Cl}_{2}$ extract of $A$. inulifolium roots (a) $750 \mathrm{mg} / \mathrm{L}$ (b) $2500 \mathrm{mg} / \mathrm{L}$.

Table 3. Diameters of the inhibition zones given by different concentrations of root dichloromethane extract of $A$. inulifolium (2500 mg/L and $750 \mathrm{mg} / \mathrm{L})$.

\begin{tabular}{cccc}
\hline \multirow{2}{*}{ Concentration $/(\mathrm{mg} / \mathrm{L})$} & \multicolumn{3}{c}{ Diameter of the inhibition zone $( \pm 0.5 / \mathrm{mm})$} \\
\cline { 2 - 4 } & Trial 1 & Trial 2 & Trial 3 \\
\hline 2500 & 24.0 & 27.0 & 23.0 \\
\hline 750 & 16.0 & 14.0 & 18.0 \\
\hline
\end{tabular}

\section{DISCUSSION}

When consider the extraction of potentials of bioactive compounds in $A$. inulifolium, the $\mathrm{CH}_{3} \mathrm{OH}$ extracts recorded a higher yield than that of $\mathrm{CH}_{2} \mathrm{Cl}_{2}$ extracts. This may be due to the higher content of polar compounds in $A$. inulifolium compared to that of non-polar compounds. Cytotoxic results suggested that $A$. inulifolium roots, flowers and leaves contain cytotoxic compounds which can be useful as antiproliferative and antitumor activities, as well as pesticidal and other bioactive agents. There is evidence to support that natural cytotoxic compounds are good contenders for anticancer drugs (Rahman et al., 2001). In addition, these cytotoxic compounds also play an important role in these plants to minimize pest attacks compared to co-existing natives, determining their successful establishment in their introduced ranges (McGraw and Eloff, 2008).

The effects of bioactive compounds on seed germination have been tested using germination index (GI) in previous studies (Chiapuso et al., 1997). GI is considered as a sensitive indicator of phytotoxic effects (Ahmed and Wardle, 1994). Results showed that germination of tested species were affected by all extracts which either delayed or reduced germination of all test seeds. However, a significantly higher phytotoxic effect was detected in $\mathrm{CH}_{3} \mathrm{OH}$-leaf and $\mathrm{CH}_{2} \mathrm{Cl}_{2}$-root extracts of $A$. inulifolium $(\mathrm{P}<0.001)$. The $\mathrm{CH}_{3} \mathrm{OH}$-leaf extract at $3000 \mathrm{mg} / \mathrm{L}$ showed the most pronounced impact against amaranth seeds with GI of $3.74 \%$. The analysis showed that $\mathrm{CH}_{2} \mathrm{Cl}_{2}$-flower extract had no significant effect on the GI $(\mathrm{P}<0.05)$ of both monocot and dicots, although it has declined the seed germination. The degree of effect on germination increased with the increasing concentrations of extracts and this was evident in extracts of all plant parts of $A$. inulifolium. The delayed seed germination can have important biological implications, as this can negatively affect the establishment of seedlings of cooccurring natives (Chaves et al., 2001), and thereby increasing the chances of competing for resources with neighbouring species (Xingxinag et al., 2009).

However, the effect was more pronounced in $\mathrm{CH}_{3} \mathrm{OH}$ extracts of $A$. inulifolium, where polar compounds are commonly found. Methanolic extracts of some plant species were known to contain phenolics and other toxic substances (Belicova et al., 2001; Al Harun et al., 2015). These phenolics may inhibit the germination process through their interference in the indole acetic acid metabolism, or synthesis of protein and 
iron uptake by plants (Blum, 1998; Castro et al., 1984).

Phytotoxic results showed that the root and shoot development of germinating test seeds are highly inhibited by the $\mathrm{CH}_{2} \mathrm{Cl}_{2}$ extracts of root and stem, and by all extracts of $\mathrm{CH}_{3} \mathrm{OH}$. In contrast, slight stimulatory effects on the root and shoot growth of monocot seedlings was shown by $\mathrm{CH}_{2} \mathrm{Cl}_{2}$ extracts of leaves and flowers. The shoot growth appeared less sensitive to $A$. inulifolium extracts than the radicle, which eventually grows into roots. The phytotoxic compounds are highly active against meristmatic tissue in growing roots. This perhaps is the reason for differing responses of root and shoot to $A$. inulifolium extracts. Phytotoxicity has been suggested as the key strategy for the impressive success of many invasive plants that has been dominated in their invaded plant communities (Ridenour and Callaway, 2001).

In some instnaces, there were slight stimulatory effects on root and/or shoot by different extracts of A. inulifolium. According to results, inhibition or stimulation of root and shoot and the germination index varied with plant extract, concentration and seed type. The stimulatory bioactive compounds can be used to develop eco-friendly, cheap and effective Green Growth Promoters (Oudhia et al., 1998). Phytotoxic compounds inhibit germination and seedling growth probably by affecting cell division and elongation, processes that are very important at early stages, or by interfering with enzymes involved in the mobilization of nutrients necessary for germination (Batlang and Shush, 2007).

Antioxidant results revealed that the $\mathrm{MeOH}$ extract of leaves contains compounds with antioxidant activity. Generally, plant polyphenolic compounds are responsible for antioxidant activity. In addition, they also act as iron chelators. The latter property may be important in an invasive plant like $A$. inulifolium where it contributes to altering the soil bacterial flora in their growing habitats (Morel et al., 1993).

In the antifungal assay, larger inhibition zones were observed with $\mathrm{CH}_{2} \mathrm{Cl}_{2}$ extracts, suggesting that the solvent has the potential to extract many active antifungal compounds. Chromene, an antifungal compound, found in roots of the invasive plant Eupatorium riparium which also belongs to the same genus as $A$. inulifolium (Bandara et al., 1992). Furthermore, the antifungal, phytotoxic and antioxidant activities were also tested in essential oils extracted from roots and inflorescence of Eupatorium adenophorum (Ahluwalia et al., 2014), further supporting this genus's worldwide distribution.

\section{CONCLUSIONS}

The results suggest that $A$. inulifolium contained phytotoxic, cytotoxic and antifungal activities. The presence of phytochemicals in A. inulifolium may suppress the growth of other plants in the habitat they invade. Cytotoxic compounds can kill pests thereby minimizing pest attacks. Antifungal compounds can reduce fungal attacks on the plant too. These characteristics can favour invasive species to invade and establish in their introduced ranges successfully. Therefore, the survival and spread of $A$. inulifolium may have been favored by the presence of these phytotoxic compounds where they can inhibit the growth of co-habiting plants. These factors may have contributed to the aggressive nature of $A$. inulifolium.

\section{REFERENCES}

Ahluwalia, V., Sisodia, R., Walia, S., Sati, O.P., Kumar, J. and Kumdu, A. (2014). Chemical analysis of essential oils of Eupatorium adenophorum and their antimicrobial, antioxidant and phytotoxic properties. Journal of Pest Science 87 (2): 341-349.

Ahmed, M. and Wardle, D.A. (1994). Allelopathic potential of vegetative and flowering ragwort (Senecio jacobaea L.) plants against associated pasture species. Plant and Soil 164(1): 61-68.

Bandara, B.M.R., Fernando, I.S.H., Hewage, C.M., Karunaratne, V., Adikaram, N.K.B. and Wijesundara, D.S.A. (1989a). Antifungal activity of some medicinal plants of Sri Lanka. Journal of the National Science Council of Sri Lanka 17(7): 1-13.

Bandara, B.M.R., Hewage, C.M., Karunaratne, V. and Adikaram, N.K.B. (1989b). Methyl ester of para-coumaric acid: antifungal principle of the rhizome of Costusspeciosus. Planta Medica 5: 477-478.

Bandara, B.M.R., Cortez, D., Jayasinghe, L., Karunaratne, V., Wannigama, G.P. and Sotheeswaran, S. (1989c). Aphorphine alkaloids from Litsea gardineri and Actinodaphne speciosa. Planta Medica 55: 393.

Bandara, B.M.R., Hewage, C.M., Jayamanne, D.H.L.W., Karunaratne, V., Adikaram, N.K.B., Pinto, M.R.M. and Wijesundara, D.S.A. (1990a). Biological activity of some steam distillates from ten species of Rutaceae Plants. Journal of the National Science Council of Sri Lanka 18 (1): 71.

Bandara, B.M.R., Jayasinghe, L., Karunaratne, V., Wannigama, G.P., Bokel, M., Kraus, W. and Sotheeswaran, S. (1990b). Isolation of pheanthine from Cyclea burmanai. Planta Medica 56: 245. 
Bandara, B. M. R., Hewage, C. M., Karunaratne, V., Wannigama, G. P. and Adikaram, N. K. B. (1992). An Antifungal Chromene from Eupatorium riparium. Phytochemistry 31: 1993.

Batlang, U. and Shushu, D.D. (2007). Allelopathic activity of sunflower (Helianthus annuus L.) on growth and nodulation of bambara groundnut (Vigna subterranean (L.) Verdc.). Journal of Agronomy 6(4): 541-547.

Belicova, A., Krizkova, L., Nagy, M., Krajcovic, J. and Ebringer, L. (2001). Phenolic acids reduce the genotoxicity of acrdine orange and ofloxacin in Salmonella typhurium. Folia Microbiologica 46(6): 511-514.

Blair, A.C., Nissen, S.J., Brunk, G.R. and Hufbauer, R.A. (2006). A lack of evidence for an ecological role of the putative allelochemical $( \pm)$-catechin in spotted knapweed invasion success. Journal of Chemical Ecology 32:2327-2331.

Blum, U. (1998). Effects of microbial utilization of phenolic acids and their phenolic acid breakdown products on allelopathic interactions. Journal of Chemical Ecology 24: 685-708.

Budzianowski, J. and Budzianowska, A. (2006). Chromatographic and spectrophotometric analyses of the DPPH free radical scavenging activity of the fractionated extracts from Lamium album L., Lamium purpureum L. \& Viscum album L. Herba Polonica 52(1/2): 51 57.

Callaway, R.M. and Aschehoug, E.T. (2000). Invasive plants versus their new and old neighbors: A mechanism for exotic invasion. Science 290:521-523.

Callaway, R.M. and Ridenour W.M. (2004). Novel weapons: a biochemically based hypothesis for invasive success and the evolution of increased competitive. Frontiers in Ecology and the Environment 2:436-433.

Castro, P.R.C., Rodrigues, J.C., Viega, R.F.A., Lima, G.P.P., Jureidin, P. and Denbandal, I.M. (1984). Allelopathic action of some weed extracts on rice (Oryza sativa L.). Agriculturist 41(1): 369-381.

Chaves, N., Sosa, T. and Escudero, J.C. (2001). Plant growth inhibiting flavonoids in exudate of Cistus ladanifer and in associated soils. Journal of Chemical Ecology 27 (3): 623-631.

Chiapuso, G., Sanchez, A. M., Reigosa, M.J., Gonzaiez, L. and Pellissier, F. (1997). Do germination indices adequately reflect allelochemical effects on the germination process? Journal of Chemical Ecology 23(11): 2445- 2453.

Chung, I.M., Ahn, J.K. and Yun, S.J. (2001). Assessment of allelopathic potential of barnyard grass (Echinochloa crus-galli) on rice
(Oryza sativa L.) cultivars. Crop Protection 20(10): 921-928.

Duke, S.O., Blair, A.C., Dayan, F.E., Johnson, R.D., Meepagala, K.M., Cook, D. and Bajsa J. (2009). Is catechin a novel weapon of spotted knapweed (Centaurea stoebe)? Journal of Chem Ecology 35:141-153.

Ens, E.J., Bremner, J.B., French, K. and Korth, J. (2009). Identification of volatile compounds released by roots of an invasive plant, bitou bush (Chrysanthemoides monilifera spp. rotundata), and their inhibition of native seedling growth. Biological Invasions 11:275287.

Al Harun M.A.Y., Johnson J., Uddin M.N. and Robinson R.W. (2015) .Identification and Phytotoxicity Assessment of Phenolic Compounds in Chrysanthemoides monilifera subsp. monilifera (Boneseed). PLoS ONE 10(10): e0139992. doi:10.1371/journal.pone. 0139992.

Haluwana, N. and Madawala, H.M.S.P. (2013). Changes in Plant Diversity and Composition across Forest Edges Bordered by Austroeupatorium inulifolium Invaded Grasslands in the Knuckles Conservation Area, Sri Lanka. Ceylon Journal of Science (Biological Sciences) 42(2): 29-43.

Hewage, C.M., Bandara, K.A.N.P., Karunaratne, V., Bandara, B.M.R. and Wijesundara, D.S.A. (1997). Insecticidal Activity of some Medicinal Plants of Sri Lanka. Journal of the National Science Council of Sri Lanka $\mathbf{2 5}$ (3): $141-150$.

Hewage, C.M., Bandara, B.M.R., Karunaratne, V., Wannigama, G.P., Pinto, M.R.M. and Wijesundara, D.S.A. (1998). Antibacterial activity of some medicinal plants of Sri Lanka. Journal of the National Science Foundation of Sri Lanka 26(1): 27-34.

Kitsati, N., Fokas, D., Oyuzouni, M-D., Mantzaris, M.D., Barbouti, A. and Galaris, D. (2012). Lipophilic caffeic acid derivatives protect cells against $\mathrm{H}_{2} \mathrm{O}_{2}$-induced DNA damage by chelating intracellular iron. Journal of Agricultural and Food Chemistry 60: 787307879.

Madawala, S., Chandrasiri, I., Diwakara, S., Wijesundara, S. and Karunaratne, V. (2014). Bioactivities of invasive plant Austroeupatorium Inulifolium, Proceedings of the University of Peradeniya Research Sessions 18: 477.

McGraw, L.J. and Eloff, J. N. (2008). Ethnoveterinary use of Southern African plants and scientific evaluation of their medicinal properties. Journal of Ethnopharmacology 119:559-574.

McLaughlin, J.L. (1982). Brine shrimp: a convenient general bioassay for active 
constituents. Planta Medica 45: 31-32.

Morel, I., Lescoat, G., Cogrel, P., Sergent, O., Pasdeloup, N., Brissot, P., Cillard, P. and Cillard, J. (1993). Antioxidant and ironchelating activities of the flavonoids catechin, quercetin and diosmetin on iron-loaded rat hepatocyte cultures. Biochemical Pharmacology 45(1):13-9.

Oudhia, P., Kolhe, S.S. and Tripathi, R.S. (1998). Allelopathic effect of Blumealacera L. on rice and common Kharif weeds. Oryza 35(2), 175177.

Rahman, M.M., Habib, M.R., Hasan, S.M.R., Sayeed, M.A. and Rana, M.S. (2011). Antibacterial, aytotoxic and antioxidant potential of methanolic extract of Phyllanthusacidus L. International Journal of Drug Development and Research 3(2): 154161.

Randall, R.P. (2012). A global compendium of weeds. $2^{\text {nd }}$ Edition. Department of Agriculture and Food, Western Australia.

Ratnayake, R., Karunaratne, V., Bandara, B. M. R, Kumar, V., Macleod, J.K. and Simmonds, P. (2001). Two new lactones with mosquito larvicidal activity from three Hortonia species Journal of Natural Products 61:376-378.

Ridenour, W.M. and Callaway, R.M., (2001). The relative importance of allelopathy in interference: the effects of an invasive weed on a native bunchgrass. Oecologia 126(3), 444450

Saito, Y., Matsuo, S., Sutoyo, A. and Tori, M. (2011). Nine new norlabdane diterpenoids from the leaves of Austroeupatorium inulifolium. Helvetica Chimica Acta 94 (2): $313-326$.

Shao, H., Peng, S.L., Wei, X.Y., Zhang, D.Q. and Zhang, C. (2010). Potential bioactive compounds from an invasive weed
Mikaniamicrantha H.B.K. Journal of Chemical Ecology 31:1657-1668.

Thorpe, A.S., Thelen, G.C., Diaconu, A. and Callaway, R.M. (2009). Root exudate is allelopathic in invaded community but not in native community: Field evidence for the novel weapons hypothesis. Journal of Ecology 97:641-645.

Wijesundara, S., Kathriarachchi, H.S., Ranasinghe, S.W. and Hapuarachchi, G. (2012). Analysis of seed plants of Sri Lanka. In: The National Red List 2012 of Sri Lanka; Conservation Status of the Fauna and Flora. Weerakoon, D.K. \& S. Wijesundara Eds., Ministry of Environment, Colombo, Sri Lanka. 340-345 pp.

Williams, D. E., Loganzo, F., Whitney, L., Togias, J., Harrison, R., Singh, M.P., McDonald, L.A., Kathirgamanathar, S., Karunaratne, V. and Andersen, R.J. (2011). Depsides isolated from the Sri Lankan lichen Parmotrema sp. exhibit selective Plk1 inhibitory activity. Pharmaceutical Biology 49(3):296-301. Xie, L.J., Zeng, R.S., Bi H.H., Song, Y.Y., Wang, R.L., Su, Y.J., Chen, M., Chen, S. and Liu, Y.H. (2010). Allelochemical mediated invasion of exotic plants in China. Allelopathy Journal 25:31-50.

Xingxinag, G., Li Zongjung, M.G., Changsong, L. and Zuowen, S. (2009). Allelopathic effects of Hemister palyrata on the germination and growth of wheat, sorghum, cucumber, rape and radish seeds. Weed Biology and Management. 9: $243-249$.

Yan, J., Bi, H.H., Liu, Y.Z., Zhang, M., Zhou, Z.Y. and Tan, J.W. (2010). Phenolic Compounds from Merremia umbellata subsp. orientalis and their allelopathic effects on Arabidopsis seed germination. Molecules 15:8241-8250. 